\title{
The Verbal Configuration in Cell Ads Language (A Critical Discourse Analysis)
}

\author{
Emma Bazergan \\ Universitas Muslim Indonesia Makassar \\ Bazerganemma@yahoo.com.au
}

\begin{abstract}
The study is about the phenomena of the verbal configuration in cell ads language. It is describing the forms and meanings as well as the social factor behind the Cell ads. The object of the study is all cell ads in Makassar that have been introduced in media whether visual or non-visual. The study is descriptive by introducing Bourdieu's social theory towards Nourman Fairlough's CDA approach and declares the new perspective from both sides.
\end{abstract}

Keywords: CDA, Hidden agenda, cell ads

\section{INTRODUCTION}

Crystal (1992) defined language as the systematic, conventional use of sounds, signs or written symbols in a human society for communication and self-expression. Language has a great impact towards people and their behavior. This is mainly true in the fields of marketing and advertising. In advertising, language as a tool of communication is used to deliver specific messages with the intention of influencing, convincing, and informing people. These specific messages mostly aim to persuade people to buy certain products or services.

Various types of mobile services have been presented by the service providers in any part of Indonesia. Indeed, media campaign which is used to convince mobile phones users has become such a tool in the process of delivering meaning for the practicality of life. With such networking opportunities, corporate service providers offer a variety of advantages in searching for their customers. However, the language used in the advertisements especially in the electronic media oftenly does not conform to the rules of good and correct language.

By using language, discourse producers can create an image to the audience as the best or most powerful figure. With this discourse interaction, Fairclough (2001) classified some provide levels of analyzing meaning called three dimensions model that could cover written texts such as microstructure (production process) that can describe a text representation, mesostructure (process interpretation) which is focused on two aspects of text production and text consumption, and a macrostructure (process discourse) the phenomena in which the text is made. These models are aimed to explore the relationship among form, meaning, and ideology that represent a content to dominate the mechanism of language and power. In this situation, language has a potential counter-image that is labeled as comfortable and acceptable ads. This model was explained more detail in comparing with Bourdieu's ideas (1989) that describes linguistic analysis of language activity is not enough, because it will only entail the study of languages which are homogeneous. The choice of language is also determined by the linguistic market, where discourse is produced.

A successful advertisement, according to Vestegaard and Shodder (1985) is expected to accomplish five functions: (1) attracting attention; (2) commanding interest; (3) creating desire; (4) inspiring conviction; and (5) provoking action. All these five functions are related each other and serve to promote the selling power of the advertised product.

\section{THEORETICAL BACKGROUND}

In order to know the meaning, the purpose, the message, and the implication behind the advertisement of cell ads in Makassar, the structure and the language of cell ads as well as visual or non-visual are analyzed. Then, the cell ads is analyzed from the language that lies in the headline, body copy, signature line, and the standing detail as seen in the illustration

The study focuses on the analysis of language cell ads, namely a printed cell ads of Telkomsel and Indosat which are displayed and introduced in Makassar. The primary data utilized in the streets or citizen houses, are very dynamic and random sampling

The method of collecting the data in this study was observation method as proposed by Sudaryanto (1988). The observation method was applied by observing thoroughly the printed cell ads. This method was implemented by note taking technique in order to collect the relevant data. The note taking technique was used to identify and classify the data. Firstly, the data were classified in order to analyze the heading, the body text, the slogan, and the icon of server. After that, the printed message was observed one by one to gain the language, the diction, the phrase and the sentence.

The method applied in analyzing the data in this study was qualitative study as proposed by Huberman (1992). This study used a text as a qualitative data source which was observed attentively. The data were classified in accordance with the theory of discourse analysis which is applied in this study. Then the analysis was presented through informal method, a method of presenting the analysis by using words to describe the finding (Sudaryanto, 1988) 


\section{RESULTS}

The structure of the advertisement of The Cell Ads, can be described as follows: Headline is the most important part of an ads. It is very first thing that is read by the customer and should arise the interest of the customer. Headline usually appears in the top of an ads and printed in the bold types of different sizes. The headlines of this ads are: an embodiment of indigenous design, luxury perfected, detailed in service, and tasteful memories in ultimate comfort.

There are many different types of headings such as the news headlines, the guarantee headline, the how to headline, the benefit headline, the question headline, the testimonial headline, the command headline, the persuasive headline, etc.

From the detailed explanation on the headline, the researcher then separated the phrase and the diction that are used in cell ads. This is to find out the illustration in drawings and show the product in use with the brand name that strengthens the concept of cell ads. There are of course some pictures or visual messages of this ads that are shown such as: a body copy analysis of the configuration dynamic in a cell ads is made by examining two elements of discourse namely euphemization and censorship.

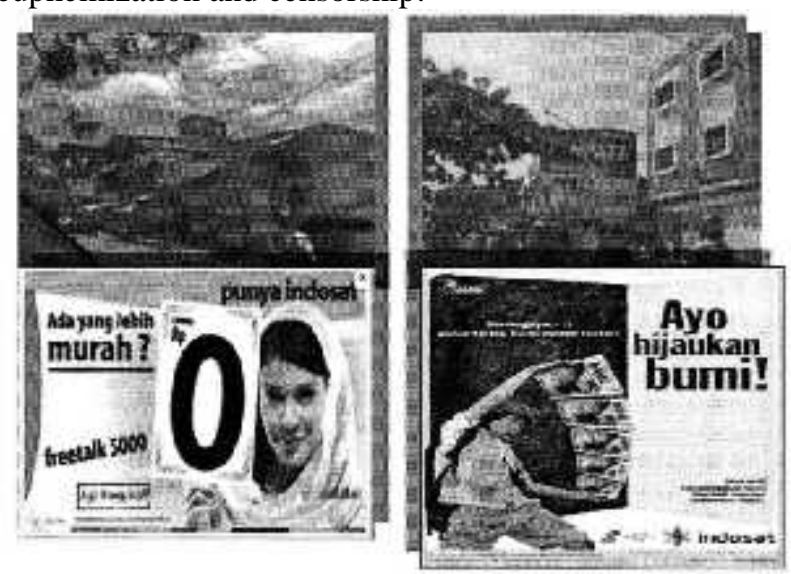

Figure 1. Examples of the Cell Ads

Euphemization is symbolic violence mechanism that works unobserved, not recognized, and takes place under the sub consciousness. Euphemization can be in the forms of trust, obligation, loyalty, courtesy, gift, reward, and compassion (Rusdiarti, 2003:38-39).

From the examples given above, it can be concluded that euphemization works on the basis of necessity and goodness. Trust, obligation, and willingness are the forms of euphemization created on the basis of necessity. The mechanism is worked by creating a cognitive situation for the subject in a state of no choice. Euphemization in the form of good manners, merit, and compassion works unnoticed to create the impression of goodness. Virtues are infiltrated to uphold or strengthen the influence and the seize of power. Furthermore, censorship mechanism makes symbolic violence appear as a form of preservation of all values regarded as "moral-honor" (Rusdiarti, 2003:39). Moral honor is grouped into two conflicting parts namely needs morale and prestigious morale. Prestigious morale embodies virtues, such as modesty and chastity. In contrast, needs moral is the embodiment of bad values such as immorality and crimes.

\section{The Verbal Configuration in Cell Ads Language}

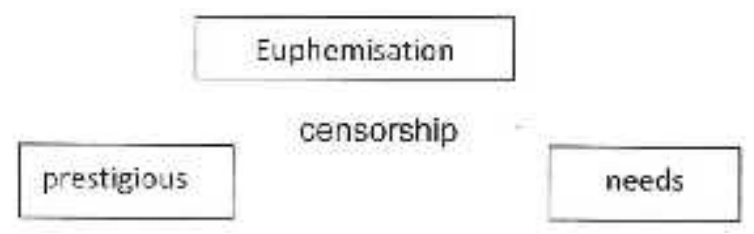

Figure 2. the signature line in this configuration dynamic language mechanism works through euphemization and censorship

In the picture, it is appeared that the signature line in this configuration dynamic language mechanism works through euphemization and censorship. Sometimes it is not detail in printing but just as a smoke eyes as Verbal Configuration for communication channels. Those can occur either written or unwritten. To express something, we use words by words. But in practice, the word cannot be said as the largest grammatical unit. As a word cannot be understood without the other words, the word is pronounced in a separate time and place. It is therefore called as the prior knowledge or background knowledge. Wake or series of words - these words will also establish the meaning or the purpose of its own. If it is separated then the word cannot be understood, and it can be referred to the meanings generated by the context or the meaning of the context.

\section{CONCLUSION}

This study is aimed at describing a cell ads in Telkomsel and Indosat server in Makassar, especially to know the configuration of phrase and sentence in the purpose of message and function and the implication behind. The analysis is done based on the theory proposed by Bourdieu (1991) and Fairclough (1995)

Overall, the text organization formed in the cell ads is displayed clearly in the middle of the signature line. The server's name is the most important thing that attracts and interests the target audience. In this case, everybody knows and realizes that cellular as the one and only tools of important communication not only in Makassar but also the whole entire world.

\section{REFERENCES}

Bourdieu, P. (1989). Practical Reason. Cambridge: Polity originally Published as Raisons Pratiques: sur la theorie de L'action (Paris:Sevill)

Bourdieu. (1991). Language and Symbolic Power (transl.). Oxford: Polity Press.

Bourdieu. (1991). Language and Symbolic Power. Cambridge, Massachusetts: Harvard University Press. Crystal, D. 1992. An Encyclopedic: Dictionary of Language 
and Languages. England: Penguin Books.

Fairclough, N. (1995). Critical Discourse Analysis: The critical Study of Language. London and New York, Longman, p.76.

Fairclough, N. (2001). Language and Power. England: Pearson Education Limited.

Huberman, M. (1992). Analisis Data Kualitatif. London: Sage Publication.

Rusdiarti, S. R. (2003). Bahasa, Pertarungan Simbolik, dan Kekuasaan, dalam Basis VII/11-12 (31-40).

Sudaryanto. (1988). Metode Linguistik (bagian pertama kea rah memahami metode linguistic). Yogyakarta: Gadjah Mada Univ Pres.

Vestegaard. T. \& Shrodder. (1985). The Language of Advertising. Oxford: Blackwell Publisher Ltd. 